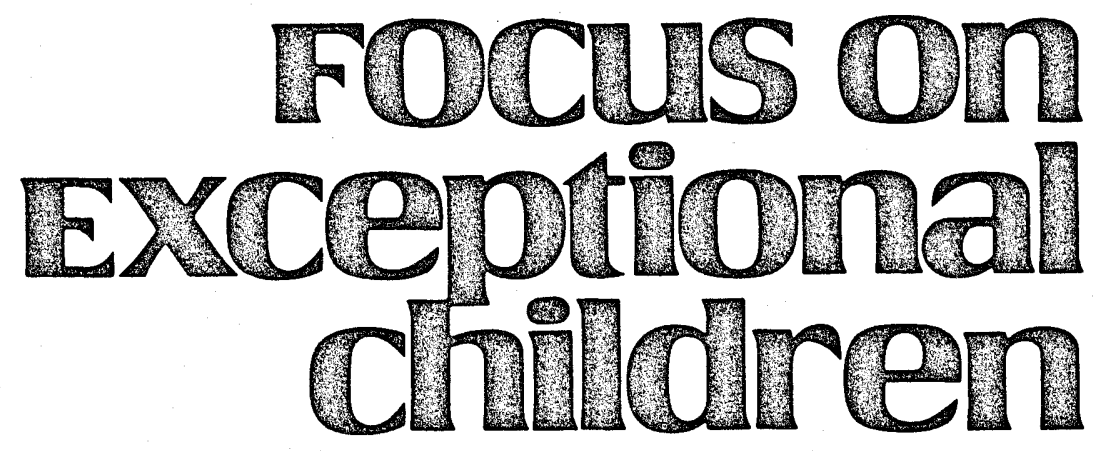

\title{
Providing Education to Students \\ With Complex Health Care Needs
}

Donna H. Lehr

Ever since enactment of the Education for All Handicapped Children Act (PL 94142) in 1975, school districts have been opening their doors to students who pose greater and greater challenges to their teachers and administrators. The newest challenge is that of providing education to students with complex health care needs (Sirvis, 1988; Viadero, 1987). There has been a long tradition of providing education to students with chronic illnesses such as diabetes, asthma, spina bifida, sickle cell anemia, hemophilia, cystic fibrosis, and muscular dystrophy (cf. Hobbs, Perrin \& Ireys, 1985; Kleinberg, 1982). But typically when those students' conditions progressed to the point that they needed health care services such as catheterization, respiratory therapy, tube feeding ventilation or oxygen, they were hospitalized or remained at home and did not attend school. The school(s) usually made adjustments for their absences or provided home or hospital instruction until their condition improved.

Now students are not automatically removed from schools for prolonged periods when they need complex health care services. After their medical conditions stabilize, students with chronic illnesses or other complex health care needs requiring specialized, skilled care, and possibly medical technology to support them, are coming to today's schools. Schools may have to take measures to ensure that serious communicable diseases are not spread within the school. The special needs student may require apnea monitoring, tube feeding, mechanical or machine suctioning, mechanical ventilation, oxygen, or other health care that is different, and often much more complex, than the schools typically have provided in the past.

Kathy, an 8-year-old student, is an example of such a child currently attending a public school. She was a healthy, normally developing child until age 2 , when she wandered out of the family's summer cottage and found her way to the lake, where she nearly drowned. Kathy was in a coma for 4 weeks. Upon discharge from the hospital after regaining consciousness, Kathy was no longer able to walk, talk, or eat by herself.

Kathy has difficulty swallowing and coughing-processes necessary to deal with food and saliva present in her mouth and throat. Consequently, Kathy cannot eat food by mouth, but instead is fed through a tube that enters directly into her stomach. Because she is unable to deal with the build-up of saliva and mucus in her mouth and throat, especially when she gets a cold, those fluids must be removed frequently by use of a suctioning machine. The machine has a long tube that is inserted into her mouth, and into her throat, when necessary, to remove the excessive fluid.

Dr. Lehr is associate professor, Department of Special Education, Boston University. This article is an adaptation of D.H. Lehr (1990), "Students with Complex Health Care Needs in Today's Schools", in E.L. Meyen (Ed.), Exceptional Children in Today's Schools (Denver: Love Publishing Co.) 


\section{EMERGENCE OF THE NEW POPULATION OF STUDENTS}

Students like Kathy are present in increasing numbers in our schools. Why weren't they in the schools before? Among the reasons are technological advances in medicine, greater acceptance of the principle of normalization, an increase in programs for young children and those with severe handicaps (Lehr \& Noonan, 1989), and increased group care of children with communicable diseases in schools.

\section{Medical Technology}

Improvements in medical technology have had two major consequences for students who have complex health care needs. First, children with serious health conditions are living longer than previously was possible. In the past, many children born prematurely with low birth weight, with congenital birth defects, or who acquired injuries after

\section{Focus on
Exceptional children}

ISSN 0015-511X

FOCUS ON EXCEPTIONAL CHILDREN (USPS 203-360) is published monthly except June, July, and August as a service to teachers, special educators, curriculum specialists, administrators, and those concerned with the special education of exceptional children. This publication is annotated and indexed by the ERIC Clearinghouse on Handicapped and Gifted Children for publication in the monthly Current Index to Journals in Education (CIJE) and the quarterly index, Exceptional Children Education Resources (ECER). It is also available in microfilm from Xerox University Microfilms, Ann Arbor, MI. Subscription rates: Individual, \$27 per year; institutions, $\$ 36$ per year. Copyright (C) 1990, Love Publishing Company. All rights reserved. Reproduction in whole or part without written permission is prohibited. Printed in the United States of America. Second class postage is paid at Denver, Colorado. POSTMASTER: Send address changes to:

$$
\begin{gathered}
\text { Love Publishing Company } \\
\text { Executive and Editorial Office } \\
1777 \text { South Bellaire Street } \\
\text { Denver, Colorado } 80222 \\
\text { Telephone (303) } 757-2579
\end{gathered}
$$

Edward L. Meyen University of Kansas
Glenn A. Vergason Georgia State University
Richard J. Whelan University of Kansas Medical Center birth did not survive long enough to become students as they are doing now (Lehr \& Noonan, 1989). Now, although they may survive, it is often with continued disabilities, sometimes very severe. The effort to save all children in distress has resulted in more students with severe handicapping conditions.

Improvements in medical technology also have resulted in the development of equipment to monitor and support these children's lives. Much of that equipment is now smaller than in the past, portable, and, in some cases, battery-operated. This enables children to be much more mobile than before. Children previously confined to places with electrical outlets can now move much more freely in their communities-attend picnics, participate in playground activities, and be transported in family cars and school buses, making attendance at school possible.

\section{The Principle of Normalization}

Changes in people's attitudes toward the care of individuals with disabilities also accounts for the increased numbers of individuals with complex health care needs in the schools. In the past, the usual practice was to segregate such individuals from the mainstream of society. Wolfensberger's (1972) principle of normalization called for the most normal environmental routines for all individuals, to obtain the most normal behaviors from the individuals. The philosophy was put into action through the deinstitutionalization movement and through the movement to place individuals with disabilities in the least restrictive placements appropriate to meet their needs. In the field of education, the principle of the least restrictive environment, set forth in PL 94-142, represents an embodiment of this philosophy. The result of all of this is that, now, efforts are being made to place all students, including those with complex health care needs, in the least restrictive, most like normal placement appropriate for each individual student.

\section{Programs for Young Children and Those with Severe Handicaps}

The third reason for the increase in numbers of students with complex health care needs in the schools is the increase in programs for very young students. PL 94-142 mandated programs for students to age 5 , with incentives for students down to age 3 . The 1986 amendment to that law, PL 99-457, mandates programs to age 3 in all states receiving federal funds, and further incentives for providing services to birth. Consequently, we have seen a steady 
increase in the number of programs serving young children with handicapping conditions. This young population of children has been the beneficiary of the improved medical technology, and consequently the children who survive with their birth defects but not without continued disabilities or complex health care needs.

PL-94-142 also requires school districts to serve all students including those with the most severe handicaps. This is the population of students that we see in the greatest number of those with accompanying medical needs (Hotte, Monroe, Philbrook, \& Scarlata, 1984).

\section{Group Care of Children with Communicable Diseases}

Among children with severe handicaps are many who do not have control of body functions and require care such as feeding and toileting or diaper changing. Group care of children who do not control their body functions and who, as all young children do, explore their environment by mouthing things, increases the risks of transmitting contagious diseases unless careful attention is paid to hygienic care of students. Among the diseases of concern are the common cold, as well as more serious diseases such as cytomegalovirus, hepatitis, herpes, and a new concern, HIV infection.

Human immunodeficiency virus (HIV) was simply not known prior to 1982. Now, it is estimated that by 1992 it will be the leading cause of mental retardation and the fifth leading cause of death in children in this country. Although it has not yet become a frequently encountered situation in the schools, it is estimated that approximately 3,000 children in this country will be affected by it by 1991 (Tolsma, 1988). Although the number of students is not large, and the disease is not transmitted through casual contact, public concern over the presence of infected students in the schools and the deadly consequences of infection require careful attention to matters regarding their inclusion in schools.

\section{DEFINITIONS}

"Students with complex health care needs" is a term I use to describe a specific, yet heterogeneous population of students. This term may include students who are labeled in the literature as (a) having chronic illnesses, (b) being technology-dependent, or (c) being medically fragile. The term goes beyond that, however, to encompass students whose needs require delivery of education and related services in new ways, different from those traditionally provided in the schools. Use of the term is, I hope, temporary, as service delivery, after a time, is expected to become more usual and not as complex. This is not to say that meeting these students' needs will become easy but, instead, that the issues and practices will become less complex to those involved.

Definitions exist for each of the subgroups comprising this population. Children with chronic illnesses may have "conditions such as burns; trauma from physical injuries that are long standing, such as spinal cord injuries or closed head trauma; and conditions more classically defined and as chronic illnesses, such as asthma, diabetes, cystic fibrosis and cancer" (Kleinberg, 1982, p. 4). They may have "a set of conditions that affects one or more body organs and represents an active disease process. It may last many months or a lifetime" (p. 4).

These students have serious illnesses that may require special health care at some times and not at other times. This can be contrasted with the following definitions of technology-dependent and medically fragile children who require special health care continuously.

The U.S. Congress, Office of Technology Assessment (1987) defines a child who is technology-dependent as:

... one who needs both a medical device to compensate for the loss of a vital body function and substantial and ongoing nursing care to avert death or further disability. (p. 3)

The Office of Technology Assessment report continues its explanation by identifying four populations within this group: (a) children dependent on mechanical ventilators, (b) children requiring nutrition or drugs intravenously, (c) children with the need for daily mechanical respiratory or nutritional support, and (d) children with long-term dependence on mechanical devices such as apnea monitors, renal dialysis and urinary catheters, or colostomy bags.

The Task Force on Technology Dependent Children (1988) has defined a technology-dependent child as one who:

is a person from birth through 21 years of age; has a chronic disability; requires the routine use of a specific medical device to compensate for the loss of use of a life sustaining body function; and requires daily, ongoing care or monitoring by trained personnel. (p. vii)

The Council for Exceptional Children uses the term "medically fragile" to identify a population of students who "require specialized technological health care procedures for life support and/or health support during the school day" (1988, p. 1). 
The last group of students included in this population termed "students with complex health care needs" are those students attending today's schools with serious communicable diseases. Among the diseases referred to are HIV (AIDS), herpes, and hepatitis. Although many other contagious diseases exist, these stand out because of their severe disabling consequences.

\section{CHARACTERISTICS OF STUDENTS WITH COMPLEX HEALTH CARE NEEDS}

Students with complex health care needs do not demonstrate a common set of learner characteristics. The group includes students with average or above-average intellectual abilities; but others have accompanying handicapping conditions such as mental retardation or significant neuromotor disabilities (Lehr \& Noonan, 1989).

Although students with complex health care needs demonstrate tremendous variability in characteristics, they do share the following needs:

- the need to be provided with a free public educational program

- the need to be provided with an education in the least restrictive environment

- the need to have as a part of their educational program a health care plan

- the need to be treated as a child first, then a student, and not as a patient

- the need to interact with other children with and without similar health care needs.

\section{ISSUES IN PROVIDING EDUCATION TO STUDENTS WITH COMPLEX HEALTH CARE NEEDS}

Because the presence of students with complex health care needs in schools is new, many questions arise for which there are no clear answers. No federal guidelines exist, nor are there comprehensive models demonstrating the best practices. Consequently, program administrators are making difficult case-by-case decisions regarding how to serve such children (Lehr \& Noonan, 1989). Issues being addressed include:

- health care procedures to be performed in schools

- responsibility for administering the procedures

- preparation for personnel to perform the procedures

- the relationship between educational and health care service provision

- student transportation.

\section{Health Care Procedures Performed in Schools}

In the past, students requiring procedures such as tube feeding or suctioning were routinely excluded from school. The zero exclusion principle and the least restrictive principle of PL 94-142 did much to change this automatic placement decision. But considerable variation continues to exist in these decisions. Children with complex health care needs are not automatically excluded from educational programs; however, their placement might be in a hospital, at home, in a segregated school, or in regular school. Some districts' policies are to serve all students with any health care needs necessary, others exclude students who require oxygen or those with communicable diseases such as HIV (AIDS), hepatitis, or herpes.

\section{Responsibility for Administration of Procedures}

Another issue is that of who has the responsibility to provide the health care procedures. Does the responsibility belong to the school district or the family, or other health agencies? If the schools have that responsibility, who in the school should perform the procedures? Issues revolve around the question of what is related service and what is a medical service, as defined in PL 94-142.

PL 94-142 specifies that a school district must provide related services including ". . . transportation, and such developmental, corrective, and other supportive services . . . as may be required to assist a handicapped child to benefit from special education" (Section 1401(a)(17)). Medical services are defined as "services provided by a licensed physician to determine a child's medically related handicapping conditions which results in the child's need for special education and related services" (34 CFR Reg 330.13(b)(4).

In Tatro v. Texas (1983), the U.S. Supreme Court determined that clean intermittent catheterization procedures were the responsibility of the school district as a related service necessary for the student to benefit from special education. In three other court cases revolving around the provision of health care to students, one led to a decision that the necessary procedures were related services and therefore school district responsibility (Department of Education, State of Hawaii v. Dorr 1983). In the other two cases, the health care procedures were considered to be more complex than those typically provided in schools and therefore not the school districts' responsibility (Detsel $\mathbf{v}$. Ambach, 1986; Bevin, H., 1986). Clearly, the courts are demonstrating differences of legal opinion regarding what 
constitutes related versus medical services in their decision making. Consequently, with the exception on the provision of clean intermittent catheterization, responsibility for other procedures is being decided by each school district.

When a decision is made that the school district is responsible for implementing procedures, the next question becomes: Who in the district is responsible? Tremendous variability exists. A student in one school district may be having his or her needs met by a school nurse, while another student, in a neighboring district, may be cared for by an instructional aide. The primary responsibility for providing school health services to students traditionally has rested on the school nurse. Nurses have the responsibility for establishing policy and procedures, with school administration, for emergency procedures, medication administration protocols, safety measures and programs, student/personnel health services, and health education (American Nurses Association, 1983). Although many health procedures have been carried out by school nurses, some of the students attending today's schools require procedures that are different and sometimes more complex than those routinely provided. One study indicates that school nurses do not believe they are adequately trained to implement many procedures required by students now attending public schools (Hester, Goodwin, \& Igoe, 1980).

Further, nurses are not always available to provide the needed health care services. In many elementary schools a school nurse is assigned for as little as one half day per week. Obviously, this is an inadequate amount of time to meet the needs of a student who has to be tube-fed daily or one who requires suctioning hourly. Consequently, classroom teachers are routinely performing such procedures in their classrooms (Mulligan Ault, Guess, Struth, Thompson, 1988). Sirvis (1988) has pointed out, however, that in most cases even the most skilled special education teacher may be hesitant to provide for students with special health care needs.

\section{Personnel Preparation for Service Provision}

Even though they often do not feel adequately prepared to implement some of the procedures students require, school nurses, teachers, or aides may be responsible for implementing the procedures. Careful attention is being given to training those involved in the care of this population of students. What training should be provided? Who should provide it? Who should receive the training?

Several organizations are now emphasizing in their recommendations the need for policies regarding training to serve students with special health care needs. For example, the Task Force on Children with Special Health Care Needs in Iowa (1988) makes specific recommendations for both preservice and inservice training of all personnel involved with these children, including teachers, support staff, and even bus drivers.

\section{Student Transportation}

Transportation of students to school becomes another difficult decision for program administrators. Some students with special health care needs must come to school attached to their portable life-supporting or sustaining equipment. Some must receive immediate attention in case of medical emergency. The range encompasses students who are transported by family members, students transported by ambulance, and students transported on regular buses. Students are being transported with only the bus driver present or, at the other extreme, with a nurse present. In one case reported, a bus driver, who is alone in accompanying a student to and from school, has been trained to perform mechanical suctioning in the event it becomes necessary (Lehr \& Haubrich, 1988).

\section{Combining Education with Care}

How the health care procedure will relate to education is another issue of concern. The teacher should view the child as first a child and second as a student, but not as a patient. These are children with health care needs. But concern about the child's health care can overshadow educational emphases.

Some students' education may relate specifically to their care needs. It may include instructional priorities related to less resistance or increased participation in their own care. Or it may relate to increased communication regarding care needs. At the same time, the students will have educational needs like those of their peers who do not have health care needs: the need to learn basic skills and knowledge; the need to learn to function as independently as possible, the need to learn to read, write, and do arithmetic. The presence of students with complex health care needs in the schools is causing educators to rethink the definition and purposes of education.

Students with communicable diseases pose some additional questions regarding the combination of education and care. Educational institutions are not accustomed to providing hygienic care for students. Until recently, selfcare (toilet training) and self-feeding were prerequisites for 
admission into schools. Now students who lack control over their body functions are in schools, and teachers must pay careful attention to all students, but particularly to those with communicable diseases. Hygienic care procedures must become routine and unobtrusive to assure that they do not become the emphasis of, but rather a support to, the educational program.

Staff concern regarding the presence of a student with a communicable disease also may interfere with the delivery of education. The staff must be given information regarding disease transmission, methods for preventing and controlling the spread of diseases when caring for all students. In addition, maintaining confidentially of information and proper education is essential to assure that the child's rights as a citizen are not violated.

Because no definitive federal or state rules are available regarding educational service provision to students with special health care needs (Task Force on Technology Dependent Children, 1988), services provided to those students are variable and inconsistent (Hobbs et al., 1985). Although variations in services are necessary to meet students' individual needs, these differences must be based on the needs of students, not on differences in district administrative resources or interest.

\section{POLICIES FOR SERVING STUDENTS WITH COMPLEX HEALTH CARE NEEDS}

The first step in developing consistency of services may be to develop policies. Several groups and organizations have begun to develop recommendations, guidelines, or policies to guide administrators in providing educational services to students with complex health care needs. These policies address children with special health care needs in general and communicable diseases specifically.

\section{Children with Special Health Care Needs}

The Council for Exceptional Children's Task Force on Medically Fragile Students (1988) has developed specific recommendations focused on nine basic issues:

1. Determining eligibility for special education services.

2. Providing related and noneducational services.

3. Assuring equal access to appropriate educational settings in the least restrictive environment.

4. Promoting a safe learning environment for all students and professionals.
5. Assuring that health care services are delivered by appropriately trained personnel.

6. Establishing support systems for staff, students, and families.

7. Including appropriate information about students' specialized health care needs in preservice, inservice, and continuing education programs.

8. Providing appropriate and safe transportation.

9. Promoting research that assesses current and future service delivery models.

For each of these points, suggestions are made as to how they can be addressed to assure that each student with specialized health care needs receives an appropriate education program.

Iowa became the first state in the country to adopt a series of policy recommendations for dealing with children with special health care needs in the schools (Task Force on Children with Special Health Care Needs, 1988). These recommendations address the following needs:

1. To resolve issues relative to fiscal responsibility.

2. To involve health care professionals in IEP planning.

3. For statements by the Department of Education regarding evaluation and assessment practices and transportation needs.

4. For position papers on placement decision procedures, and service delivery issues including reevaluation, timelines, and care management responsibilities.

5. For the development of technical assistance and training for school personnel involved in the delivery of specialized health care for students.

6. The securement of model protocols and instructional materials for use by school nurses and staff responsible for providing health care to students.

\section{Children with Communicable Diseases}

Of the $59 \%$ of the 50 states and the District of Columbia responding to a recent survey, $70 \%$ had policies or guidelines regarding communicable disease in the schools (Lehr \& Peppey, 1988). Considerable differences, however, were observed regarding thoroughness of the guidelines or policies regarding placement, exclusion, care-providing procedures, confidentiality, and case management.

The American Academy of Pediatrics (1988) has developed policies regarding infection control of HIV (AIDS) in schools. Changes in the guidelines reflect changes in our knowledge base regarding the spread of this infectious dis- 
ease. The 1986 guidelines suggested excluding from preschool settings children infected with AIDS, which has great care-providing demands. The 1988 guidelines reflect a modification of those recommendations; these cite the risk of transmission as being so remote that there is no reason for exclusion.

The Council for Exceptional Children (1989) has developed a policy statement on managing communicable and contagious diseases in the schools. The policy emphasizes the need for case-by-case decision making, education of students and staff, protection for staff, and collaboration across agencies in policy development. The CEC policy statement also emphasizes the dynamic data base, which requires frequent review and revision of any established policies. The full text is given at the end of this article.

\section{PROGRAM PRACTICES}

Although this area of educational service delivery is relatively new, a number of recommendations regarding programs practices have been developed by those currently working with this population of students. Some of these will be discussed in the following sections. Emphasis is placed on recommendations relating to program planning, the development of communication systems, the training of involved personnel, and family-centered care management.

\section{Program Planning}

All students with needs for special education programs must have individualized education programs (IEPs) under the law. The same is true for students with special education needs who have complex health care needs. For those students, however, careful attention must be paid to developing plans that include all of the following (Caldwell, Todaro \& Gates, 1989):

- Methods for assuring communication between and among family, school personnel, and medical providers.

- Provisions for transition from hospital or home to school.

- Identification of resources for technical assistance.

- Health care and emergency plans.

- Provision of training and monitoring of education personnel.

An additional emphasis is that of including IEP objectives that specifically relate to students' health care needs. Objectives designed to increase students' tolerance of, par- ticipation in, or implementation of the procedures are critical. Examples of these are given at the end of this article.

The development of health care plans is also an important part of comprehensive planning. Health care plans should include information such as what is to be done, the purpose of the service, the frequency with which the procedures should be implemented, under what conditions the physician should be contacted, personnel who should be involved and the training they should receive, how the procedures should be implemented, and the equipment needed (Ferguson, 1988). Procedures to be followed in the case of an emergency must be included.

\section{Increasing Communication}

Students with complex health care needs usually receive services from a number of professionals, representing a number of disciplines, usually located at different geographical locations. For example, a student might attend school in his or her home community but be under the primary care of a pediatrician located in the nearest large city, 90 miles away. The student may be receiving physical therapy from the school district, and speech therapy from a private clinic in the home community. The students also may be receiving 6 hours of home health nursing services daily, by a nurse employed by a private home health care agency.

In this scenario, the student, in addition to being involved with care providers (natural or foster family or residential home staff), the teacher, physical therapist, and two paraprofessional aides in the school, is receiving direct services from three other professionals. With this many individuals involved, communication and coordination becomes a major concern. How can consistent approaches be developed? How can all be informed of critical information?

One person should be identified as the coordinator for information flow to and from the schools. Often this person is the parent or the school nurse or the teacher. Caldwell, Todaro, and Gates (1989) have pointed out that the parent is most often the person responsible for coordinating information between schools and medical professionals. Those authors also pointed out problems with this model when the parent's role as primary liaison is only assumed and not specifically established, which results in a lack of routine reporting and selective reporting and the parent making assumptions regarding what is important. The same problem may occur, of course, when the teacher's or nurse's role is not made explicit. 
A second set of important factors leading to effective coordination relates to communication attitudes and specific skills; communication attitudes such as self-acceptance, acceptance of others, and empathy have a powerful impact on the ways in which information is exchanged (Holvoet \& Helmstetter, 1989). Parents who feel that a professional is not accepting of them or their child are not likely to be open in their discussions with that individual. The consequence may be a significant barrier to the necessary exchange of information.

Specific communication skills related to listening, nonverbal communication and verbal responding are also essential to assure coordinated care (Holvoet \& Helmstetter, 1989). Among the skills necessary in these areas are careful, attentive, active listening; careful interpretation of nonverbal messages; verbal responding such as paraphrasing, summarizing, and clarifying. Development and use of these skills results in increased accuracy of the information exchanged.

Whoever is responsible for communication coordination and those who participate in the communication process have the tremendous task of collecting and transmitting accurate information to assure coordinated, consistent care of children. Without this, quality care can not be realized.

\section{Training}

Personnel involved in providing educational and specialized health care services to students with complex health care needs must be properly prepared. This is essential in providing the best possible services to students and also in reducing the risks for liability. The Iowa State Department of Education (Task Force on Children with Special Health Care Needs, 1988) has recommended that preservice training programs for special education teachers include information and training related to:

- Certification in first aid and CPR.

- Physical care, general health and nutrition information, infection control, skin care, elimination and oral hygiene, common childhood diseases.

- Community resources and how to access them.

- The team approach to service provision, confidentiality, and dealing with sensitive information.

- Effective IEP writing for children with special health care needs. (p. 7).

The Iowa Department of Education also recognized the need for ongoing training for teachers currently in the field and made recommendations for periodic inservice training on topics similar to those listed.

Additional emphasis must be placed on training staff in the hygienic care of all students to prevent spread of infection and contagious diseases. Proper handwashing has been identified as the single most important procedure for preventing the spread of infections (Silkworth, 1988). Other essential procedures to learn include the cleaning of diapering surfaces, instructional materials, and eating/feeding equipment.

The need for training regarding HIV infection is critical to assure that school professionals are informed about transmission modes. Knowledge that transmission does not occur through casual contact, or through contact with saliva or feces and urine, will contribute to the acceptance of students who test positive for HIV. This knowledge also will result in school personnel using Universal Precautions in caring for all students in the school setting. Recommendations by the American Academy of Pediatrics (1988) regarding care for students with HIV infection in the schools are:

1. HIV-infected children who are old enough to attend school can be admitted freely to all activities, to the extent that their own health permits. The child's physician should have access to consultative expertise to assist in decision making.

2. As all infected children will not necessarily be known to school officials in high-prevalence areas, and because blood is a potential source of contagion, policies and procedures should be developed in advance to handle instances of bleeding. Such policies and procedures should be based upon the understanding that even within an area of high prevalence, the risk of HIV-infection resulting from a single cutaneous exposure to blood from a school-aged child or adolescent with unknown serologic status is minute. Considering such minimal risk, the only mandatory precautionary action should be washing exposed skin with soap and water. Lacerations and other bleeding lesions should be managed in a manner which minimizes direct contact of the caregiver with blood. Schools in high-prevalence areas should provide access to gloves so that individuals who would wish to further reduce a minute risk may opt for their use. Under no circumstance should the urgent care of a bleeding child be delayed because gloves are not immediately available. 


\section{Family-Centered Care}

Former Surgeon General C. Everett Koop has been a significant leader in calling for community-based (as contrasted with hospital-based) systems of services for students with special health care needs and their families (Gittler, 1988). Strong in his message is the importance of the family as central in each child's life: "The family is the constant whereas the public and private agencies, organizations, institutions and individuals that provided health and other needed services for the child are transitory" (p. 5). The campaign calls for development of supports to assist families in their natural role as the primary providers for their children. It calls for the development of systems in which partnerships are formed between professionals and families in all aspects of planning and service provision (Gittler, 1988).

Throughout the country, many projects are emerging to develop the necessary supports for family-centered, community-based care. Programs are incorporating the following elements (Shelton, Jeppson, \& Johnson, 1987, p. 1):

- Recognition that the family is the constant in the child's life while the service systems and personnel within those systems fluctuate.

- Facilitation of parent/professional collaboration at levels of health care.

- Sharing of unbiased and complete information with parents about their child's care on an ongoing basis in an appropriate and supportive manner.

- Implementation of appropriate policies and programs that are comprehensive and provide emotional and financial support to meet the needs of families.

- Recognition of family strengths and individuality and respect for different methods of coping.

- Understanding of and incorporating the developmental needs of infants, children, and adolescents and their families into health care delivery systems.

- Encouragement and facilitation of parent-to-parent support.

- Assurance that the design of health care delivery system is flexible, accessible, and responsive to family needs.

Only through this orientation of the child as part of a family can educators working with families and other professionals from a variety of fields develop comprehensive, effective programs of education and care for children with special health care needs.

\section{SUMMARY}

Providing educational programs in least restrictive environments to students with complex health care needs is a new challenge to public schools. Many questions about the best ways to meet these students' educational and health care needs are still unanswered. Although attention to this group of students is increasing, much additional work is necessary. Solutions to these questions and issues are not simple and cannot be solved by the schools alone. Collaborative efforts among educational and medical fields and with families are essential.

Dissemination of information and preservice and inservice training of personnel are necessary to quality programs that combine education and care. It is also necessary to prevent discrimination against students and spread of communicable diseases.

\section{REFERENCES}

American Academy of Pediatrics. (1986). School attendance of children and adolescents with Human T Lymphotropic Virus III/Lymphadenopathy-Associated Virus Infection. Pediatrics, 77(3), 430432.

American Academy of Pediatrics (1988). Pediatric guidelines for infection control of HIV (AIDS) virus in hospitals, medical offices, schools, and other settings. Pediatrics, 82(5), 801-807.

American Nurses Association. (1983). Standards of school nursing practice. Kansas City, MO: American Nurses Association.

Bevin, H. In re. EHLR 508: 134, 1986.

Caldwell, T.H. (1988). Children with special health care needs in schools. Presentation at Conference Blue Print for Change, Council for Exceptional Children, Orlando, Florida.

Caldwell, T.H., Todaro, A.W., \& Gates, A.J. (1989). Special health care needs. In J.L. Bigge, Teaching individuals with physical and multiple disabilities. Columbus, $\mathrm{OH}$ : Charles E. Merrill.

Council for Exceptional Children. (1988). Report of the Council for Exceptional Children's ad hoc committee on medically fragile students. Reston, VA: Council for Exceptional Children.

Council for Exceptional Children. (1989). Policies Manual. Reston, VA: Council for Exceptional Children.

Department of Education, State of Hawaii v. Katherine D. Dorr, 727, F. 2d 809 (9th Cir. 1983).

Detsel v. Ambach (ND NY 1986, 1985-86 EHCR D EC, 557:335).

Ferguson, H. (1988). Getting school health services together. Paper presented at TASH Conference, Washington, DC.

Gittler, J. (1988). Community based service systems for children with special health care needs and their families. Iowa City: National Maternal and Child Health Resource Center.

Hester, H.K., Goodwin, L.D., \& Igoe, J.B. (1980). The SNAP School Nurse Survey: Summary of procedures and results. Project \#1846002597A1. Washington, DC: U.S. Department of Maternal and Child Health.

Hobbs, N., Perrin, J.M., \& Ireys, H.T. (1985). Chronically ill children and their families. San Francisco: Jossey-Bass Publishers. 


\section{The Council for Exceptional Children's Policy Statement on Managing Communicable and Contagious Diseases}

Controlling the spread of communicable and contagious diseases within the schools has always been a problem faced by educators, the medical profession, and the public. Effective policies and procedures for managing such diseases in the schools have historically been developed by health agencies and implemented by the schools. These policies and procedures were primarily designed to manage acute, temporary conditions rather than chronic conditions which require continuous monitoring and remove children from interaction with other children while the condition is contagious or communicable.

The increased prevalence of chronic communicable diseases such as hepatitis B, cytomegalovirus, herpes simplex virus, and acquired immune deficiency syndrome have raised public and professional concern, necessitating the reassessment of existing school policies and procedures. The Council believes that having a communicable/contagious disease does not in itself result in a need for special education. Further, the Council believes that in developing appropriate policies for managing communicable diseases, schools and public health agencies should assure that any such policies and procedures:

a. Do not exclude the affected child from the receipt of an appropriate education even when circumstances require the temporary removal of the child from contact with other children.

b. Provide that determination of a nontemporary alteration of a child's educational placement should be done on an individual basis, utilizing an interdisciplinary/interagency approach including the child's physician, public health personnel, the child's parents, and appropriate educational personnel.

c. Provide that decision involving exceptional children's nontemporary alterations of educational placements or services constitute a change in the child's Individualized Education Program and should thus follow the procedures and protections required.

d. Recognize that children vary in the degree and manner in which they come into contact with other children and school staff.

e. Provide education staff with the necessary information, training, and hygienic resources to provide for a safe environment for students and educational staff.

f. Provide students with appropriate education about communicable diseases and hygienic measures to prevent the spread of such diseases. g. Provide, where appropriate, carrier children with education about the additional control measures that they can practice to prevent the transmission of the disease.

h. Enable educational personnel who are medically at high risk in regard to certain diseases to work in environments which minimize such risk.

i. Provide educational personnel with adequate protections for such personnel and their families if they are exposed to such diseases through their employment.

The Council believes that special education personnel preparation programs should:

a. Educate students about communicable and contagious diseases and appropriate methods for their management.

b. Counsel students as to how to determine their level of medical risk in relation to certain diseases and the implications of such risk to career choice.

The Council believes that the manner in which policies for managing communicable and contagious diseases are developed and disseminated is critically important to their effective implementation. Therefore, the following must be considered integral to any such process:

a. That they be developed through the collaborative efforts of health and education agencies at the state, provincial, and local levels, reflecting state, provincial, and local educational, health, and legal requirements.

b. That provision is made for frequent review and revision to reflect the ever-increasing knowledge being produced through research, case data reports, and experience.

c. That policies developed be based on reliable identified sources of information and principles endorsed by the medical and educational professions.

d. That such policies be written in content and format to be understandable to a variety of consumers including students, professionals, and the public.

e. That policy development and dissemination be a continual process and disassociated from pressure associated with precipitating events.

Source: Council for Exceptional Children, 1989, Policies Manual (Reston, VA: Council for Exceptional Children). Reprinted by permission. 


\section{Catheterization: Individual Education Plan (IEP) Recommendations}

\section{Level 1 - Total Dependence}

Goal: (Self-Help) Maintain healthy urinary status by tolerating catheterization in a cooperative manner.

\section{Objectives:}

- The student's family will provide, on a daily basis, the equipment necessary for catheterization, $100 \%$ of time.

- The student will remain still in a lying position while the assistant performs catheterization in school at 8:00 a.m. and $12: 00$ noon, $100 \%$ of the time.

- The student will assist in assuming the correct position for catheterization when the assistant indicates it is time for the procedure, $90 \%$ of the time.

\section{Level 2 - Direction of Care}

Goal: (Self-Help) Maintain healthy urinary status and obtain maximum level of independence by learning how to direct care.

\section{Objectives:}

- The student's family will provide, on a daily basis, the equipment necessary for catheterization, $100 \%$ of time.

- The student will identify equipment needed for catheterization 4 out of 5 trials.

- The student will be able to verbalize "What comes next?" 4 out of 5 trials.

- The student will be able to independently (verbally) direct the step-by-step prescribed procedure to include the collection of materials, cleaning, catheterization, and then clean-up, 4 out of 5 trials.

- The student will be able to state warning signs and symptoms of problems related to catheterization and answer related, "What if?" questions, 4 out of 5 trials.

\section{Level 3 - Independent Completion of Catheterization}

Goal: (Self-Help) Maintain healthy urinary status through the independent completion of catheterization.

\section{Objectives:}

- The student's family will provide, on a daily basis, the equipment necessary for catheterization, $100 \%$ of time.

- The student will identify equipment needed for catheterization 4 out of 5 trials.
- The student will be able to answer questions about the procedure (i.e., "What comes next?") 4 out of 5 trials.

- The student will be able to independently (verbally) direct the step-by-step prescribed procedure for the collection of materials, cleaning, catheterization, and then clean-up, 4 out of 5 trials.

- The student will be able to independently gather equipment for the procedure, 4 out of 5 trials.

- The student will be able to demonstrate on a doll the step-by-step procedure for cleaning hands and genital area, 4 out of 5 trials. Note: This may be accomplished through the purchase of an inexpensive doll with a hole cut in the genital area.

- The student will be able to answer question, "Why are you cleaning your hands? . . . your genital area?", 4 out of 5 trials.

- The student will be able to demonstrate placement of catheter in the doll, 4 out of 5 trials.

- The student will be able to set up for self-catheterization and clean self following the prescribed step-bystep procedure, 4 out of 5 trials.

\section{Male}

- The student will be able to hold his penis in the correct position, clean himself and identify opening, insert the catheter, and follow the prescribed step-by-step procedure, 4 out of 5 trials.

\section{Female}

- The student will be able to open her labia, clean herself, and identify the urethra, insert the catheter, and follow the prescribed step-by-step procedure, 4 out of 5 trials.

- The student will be able to independently complete self-catheterization according to the prescribed stepby-step procedure, 10 out of 10 trials.

- The student will be able to state warning signs and symptoms of problems related to catheterization and answer related "What if?" questions, 4 out of 5 trials.

- The student will be able to independently complete self-catheterization according to the prescribed stepby-step procedure during monthly observation.

Source: T. Caldwell, 1988, Children with Special Health Care Needs in School (presentation at Conference Blue Print for Change, Council for Exceptional Children, Orlando, Florida). Reprinted by permission. 
Holvoet, J.F., \& Helmstetter, E. (1989). Medical problems of students with special needs: A guide for educators. Boston: Little, Brown.

Hotte, E.A., Monroe, H.S., Philbrook, D.L. \& Scarlata, R.W. (1984). Programming for persons with profound retardation: A three year retrospective study. Mental Retardation, 22(2), 75-78.

Kleinberg, S.B. (1982). Educating the chronically ill child. Baltimore: Aspen Publications.

Lehr, D.H., \& Haubrich, P. (1988). [Service Delivery Models for Students with Special Health Care Needs.] Unpublished raw data. University of Wisconsin-Milwaukee.

Lehr, D.H., \& Noonan, M.J. (1989). Issues in the education of students with complex health care needs. In F. Brown \& D.H. Lehr (Eds.), Persons with profound disabilities: Issues and practices. Baltimore: Paul H. Brookes Publishing.

Lehr, D.H., \& Peppey, K. [Review of Communicable Disease Policies of State Departments of Education]. Unpublished raw data. University of Wisconsin-Milwaukee.

Mulligan Ault, M., Guess, D., Struth, L. \& Thompson, B. (1988). The implementation of health related procedures for classrooms for students with severe multiple impairments. TASH, 13(2), 100-109.

Shelton, T.L., Jeppson, E.S., \& Johnson, B.H. (1987). Family-centered care for children with special health care needs. Washington, DC: Association for the Care of Children's Health.

Silkworth, C.S. (1988). Handwashing techniques. In G. Larson (Ed.), Managing the school-age child with a chronic health condition (pp. 141-145). Wayzata, MN: DCI Publishing.

Sirvis, B. (1988). Students with special health care needs. Teaching Exceptional Children, 20(4), 40-44.

Task Force on Children with Special Health Care Needs. (1988). Recommendations: Services for children with special health care needs. Des Moines: Iowa Department of Education.

Task Force on Technology Dependent Children. (1988). Fostering home and community-based care for technology dependent children. Washington, DC: U.S. Department of Health and Human Services.

Tatro v. Texas, 625 F. 2d 557 (5th Cir. 1980), 703 F. 2d 823 (5th cir. 1983).

Tolsma, D. (1988). Activities of Centers for Disease Control in AIDS education. Journal of School Health, 58(4), 133-136.

U.S. Congress, Office of Technology Assessment. (1987). Technology dependent children: Hospital vs. home care-A technical memorandum. (TA-TM-H-38). Washington, DC: U.S. Government Printing Office.

Viadero, D. (1987). Medically fragile students pose dilemma for school officials. Education Week, 1, 14.

Wolfensberger, W. (1972). Normalization: The principle of normalization in human services. Toronto: Canada: National Institute on Mental Retardation.

\section{TRAINING AND RESOURCE MATERIAL}

Larson, G. (Ed.). (1988). Managing the school age child with a chronic health condition. Wayzata, MN: DCI Publishing.

A book designed for all personnel in the schools who work with students with chronic health conditions; includes practical how-todo information on planning and implementing health care procedures.

California State Department of Education. (1980). Guidelines and procedures for meeting the specialized physical health care needs of students. Sacramento: author.

A manual including specific information on how to implement specialized health care procedures in the schools.

Graff, J., Mulligan Ault, M., Guess, D., Taylor, M., \& Thompson, B. (1990). Health Care for Students with Disabilities. Baltimore: Paul Brookes.

A manual to provide teachers with relevant information regarding health-related procedures their students receive.

\section{VIDEO TRAINING TAPES*}

CPR and Emergency Choking Procedures for Infants or Young Children. Introduces and reviews procedures to prevent and provide emergency treatment. 37 mins.

Clean Intermittent Catheterization. Includes information regarding benefits of, and procedures for performing, $\mathrm{CIC}$, as well as how to instruct others. 25 mins.

Home Oxygen for Infants and Young Children. Demonstrates use of three commonly used home oxygen systems emphasizing precautions for use. 30 mins.

Home Tracheostomy Care for Infants and Young Children. Reviews physiology of infant airways and procedure for caring for the child with a trach tube. 40 mins.

Infection Control in Child Care Settings. Addresses necessary concerns regarding prevention of spread of contagious diseases in group care settings and provides instruction on effective control techniques. 30 mins.

* The above are available from Learner Managed Designs, $2201 \mathrm{~K}$ West 25th St., Lawrence, KS 66046. 